\title{
24. 頭頸部悪性腫瘍の臨床的観察
}

\author{
一一当科 10 年間の集計一
}

\author{
吉野邦俊 - 佐藤武男 - 馬谷克則 - 高木 正 - 藤井 隆 -八田千広 - 前谷近秀 - 路 波 \\ (大阪府立成人病センター)
}

当科では1978年秋から，頭頸部悪性腫县を主体とし た診療を行っており，丸10年が経過した。そこで今回， 現在までの症例の集計を行い，その概略を報告した。

1979年 1 月〜1988年12月までの10年間の頭頸部悪性 腫瘍患者総数は1674例（一次例のみ）であった。年間 の平均患者数は167例となり，外来新患数に占める割合 は各年 7〜8\%であった. 発癌部位の内訳は喉頭癌が $44.1 \%$ と約半数近々を占め, 下咽頭癌 $12.8 \%$, 舌・口 热癌 $10.0 \%$, 甲状腺癌 $7.9 \%$, 中咽頭癌 $7.1 \%$, 墨性り ンパ腫 $6.2 \%$ ，上咽頭癌 $4.1 \%$ ，鼻・副鼻腔癌 $4.4 \%$ ，唾 液腺癌 $2.2 \%$ 順であった。この割合は, 各年次ともほ 仿同じで大きな変動はみられなかった。病理組織は 1772例（準悪性として混合腫瘍98例を含む） $076.6 \%$ が肁平上皮癌であり，次いで腺癌（甲状腺癌が $86.8 \%$ ) が8.1\%, 悪性リンパ腫が $5.9 \%$ の順であった。部位別 で、，喉頭癌，下咽頭癌がほほ全例屏平上皮癌であっ たのに対して, 舌・腔, 中咽頭では小唾液腺由来の 癌が散見された(各々 $8.9 \% ， 4.8 \%$ ).中咽頭では 28.7 \%が悪性リンパ腫であった。鼻・副鼻腔では多彩な組 織像がみられ，とくに肉腫系が17.5\%にみられた。年 齢分布は喉頭，中・下咽頭，舌・回空の各扁平上皮癌 とも類似した分布で50〜70歳代が大多数を占め, 調査 期間での明らかな高龄化傾向は認められなかった。性 別では堻煙・飲酒と関連した喉頭，軟口蓋〜前口蓋弓， 梨状楩凹，口腔底の各癌が男性優位（性比10以上）で あり，甲状腺と輪状軟骨後部滰は女性優位（性比は各々
$0.2,0.4)$ であった。病期は中・下咽頭癌が喉頭，舌・ 口腔癌に比べて進行癌の占める割合が高く，70〜80\% が stage III・IVであった。

喉頭癌に対して当科では定性治療を行っているが, その 5 年累積生存率 $(1979 \sim 1983, \mathrm{n}=334)$ は全体で $72.4 \%$ であり, stage I $85.7 \%$, stage II 74.7\%, stage III $61.7 \%$, stage IV 51.9\%であった。腫瘍死に限る cause specific survival rateでは全体で87.3\%とな り, 他病死, 他癌死が大きな死因を占めていた。舌・ 口腹，咽頭门各扁平上皮癌に対しては，放射線治療と 手術のどちらか単独あるいは雨者の併用を行ってきた が, 最近数年間は導入化学療法を取り入れ, 再建外科 も含めた集学治療を行っている。主として放射線治療 と手術の両者による 5 年累積生存率 $(1979 \sim 1986)$ は, 舌・口腔癌 $(n=94) 59.4 \%$ ，上咽頭癌 $(n=54) 38.4 \%$, 中咽頭癌 $(n=46) 53.3 \%$, 下咽頭癌 $(n=117) 41.3 \%$ であった，今後一層の成續向上を望むには，特に進行 癌に対する対策が必要であるが, 現実にはかなり困難 と思われる。近年盛んに用いられている化学療法や， 兔疫潦法のような何らかの新しい方法を組み合わせた 集学的治療法の発展と治療体系の確立が望まれる。

質問 高岡哲郎(静岡赤十字)。下咽頭癌の 5 年生存率 が $41.5 \%$ と他施設の成續からみると良好だが，その要 因について。応答今回報告した成䋶を誉げた要 因として，明確には分からないが，強いてあげれば症 例が多いための経験によることが考えられる。

\section{5.下咽頭癌の臨床統計}

\section{市川容子・海老原秀和・真島一彦・宮下久夫・谷川 譲（都立駒込）}

目的下咽頭癌は進行例が多く, 予後不良であるこ とは既知の事実である。しかし，当院が東京地方の癌 治療病院となってから13年が経過し，本疾患も40例を こえて他施設との比較も可能となったため，今回本疾 患の臨床統計を行った。

対象わよび方法 1975年 1月から1988年11月までの 13年11力月の間に当科を初診した下咽頭癌47例のうち 一次症例 42 例を対象とし, 性別, 年龄, 部位, 病理組 織, 初発症状, 診断確定まで過程, 病期, 治療法, 予後について統計学的観察を行った。

結果 性別は男性34例，女性 8 例 (男女比約 4:1) で 男性に多く, 年粉分布は36 83歳で平均60歳である. 部位別では梨状楩凹型34例（男女比約 $6: 1$ )。輪状軟骨
後部型 8 例 (男女比約 $2: 1$ ), 後壁型 0 例である。病理 組織型は42例全例が扁平上皮癌であった。初発症状と しては曖下時痛を含む咽頭痛15例, 咽喉頭異常感10例, 嶼下困難 7 例の順である。診断確定までの過程として 症状の発現から 1 力月以内に21例 $(50 \%)$ が医師を訪 れ，また訪医から1力月以内に27例 $(64 \%)$ の診断が 確定している.1987年版 UICC 分類による TNM 分類 では T1 6 例, T2 7 例, T323例, T4 6 例, N0 8 例, N1 11 例，N2 18 例, N3 5 例, M0 40 例, M1 2 例で, Stage 分類では Stage I 3 例, Stage II 2 例, Stage III 13例, Stage IV24例となり, Stage III 以上の進展例が 多く $(88 \%)$ なっている。次治療としては照射単独 13例(頸部郭清術 2 例), 照射後手術 1 例, 照射化学療 
法併用 2 例 (遠隔転移 1 例), 手術単独26例 (術後照射 12例，術後化療 1 例，術後照射化療 1 例）である。死 亡例25例について検討してみると原発栄に残存した症 例が14例と最も多い，原発部位では輪状軟骨後部型で は死亡例が多く，8例中 7 例が死亡している. Kaplan -Meier 法による 5 年累積生存率は他病院, 死因不明 4 例を除いた38例で36\%であった。さらに部位別の予後 と Stage IV の手術例にて求好々梨状陷山型 $42 \%$, 輪状軟骨後部型 $0 \%$ と $5 \%$ 水準で両者の間に差はある
ものの有意差を認められず, 一次治療別の予後を Stage IV の梨状陥凹型にて求めると照射単独 $20 \%$, 手 術 $42 \%$ と差を認めたものの $5 \%$ 水準で有意差を認めら れなかった。この他全症例中放射線誘発癌 3 例, 重複 癌 10 例（口腔底癌 1 例, 食道癌 2 例, 甲状腺癌 5 例, 肺癌 2 例, 膀肶癌 1 例, 直腸癌 1 例でそのうち 1 例は 下咽頭・食道・肺・膀胱の 4 重複癌症例)を認めてい る.

\title{
26. 頭頸部粘表皮様癌の検討
}

\author{
遠藤壮平・木田亮紀・古阪 徹・飯田英信（日大） 末野康平・山田洋一郎（大宮日赤） \\ 宮川智洋・桜井 勇（日大第 2 病理）
}

はじめに粘表皮様癌 mucoepidermodi carcinoma は唾液腺より発生する悪性腫崵の内 2 番目に 多い腫湟である。.今回われわれは昭和 48 年 1 月より平 成元年 4 月までの 16 年 4 力月間に日大板橋病院, 酸河 台病院，大宮日赤病院にて21例の頭頸部粘表皮様癌を 経験し，その予後決定因子の検討を行ったので若干の 文献的考察をあわせ報告した。なお生存曲線は Caplan -Meier 法にて，有意差検定はCox-Mentel 法にて求 めた。

結果 症例の内訳は男性 8 例, 女性13例で, 初猃時 の年齢は17から81歳まで，男女の年齢間で有意差はな く平均 45.5 歳であった。 初診時年路を 60 歳未満と以上 とにわけ,生存曲線を求めると,60歳以上の群が明らか に予後不良であった $(\mathrm{P}<0.005)$. 原発部位は, 大唾液 腺では耳下腺 7 例, 吅下腺 1 例の計 6 例, 口腔では口 蓋 6 例，煩粘膜 4 例の計 10 例，鼻・副鼻腔では上顎洞 1 例, 鼻腔 1 例の計 2 例, 咽頭では舌根部の 1 例であ り，部位別の予後の差は明らかではなかった。

UICC (88) のTNM 分類による各因子別に調べる と, T1 が 3 例, T 2 が 7 例, T3 が 7 例, T4 が 4 例で, $\mathrm{T} 2$ と $\mathrm{T} 4$, T3 と T4 の間に明らかな有意差があった $(\mathrm{P}<0.05)$. N 因子別には，N0 が12例，N1 が 7 例, $\mathrm{N} 2$ が 2 例で, N1の1例に肺転移を認めた. 生存率に
有意差は認めなかった。病期別には, Stage I が 3 例, Stage II が 6 例, Stage III が 7 例, Stage IV が 5 例 であり, Stage II と Stage IV の間に有意差を認めた $(\mathrm{P}<0.05)$.

18例の病理標本を再検討し 3 Grade に分けた. Low -grade $か 33$ 例, Intermediate-grade $か ゙ 7$ 例, Highgrade が 8 例であり, 生存率に関しての有意差はあき らかではなかった。治療法としては，21例中手術療法 は19例に行われその内11例が根治手術, 他の8例は準 根治手術と思われた。残りの 2 例には化学療法が，更 にその内 1 例には照射療法の併用が行われた。根治手 術群と準根治手術群, 根治手術群と非根治手術群の間 には有意差を認めた $(\mathrm{P}<0.05)$. 化学療法の奏効率は 照射併用も併せ $66.7 \%$ でった。

考察 Spiroらは，予後に影響する因子として，年 齢, 性, 組織の Grade, Stage をあげている.われわれ の症例では Grade 別では症例数が少なく有意差は䛱 められなかった. Eisenberger らは CAP 療法で再発例 に100\%（3/3）の奏効率を報告している．

まとめ 1. 頭頸部粘表皮様癌21例について検討し た. 2. 予後を决定する因子は, 年齢, T 因子, Stage, 手術の根治度であった.3. 進展例で化学療法が有効な 例があった。

\section{13年経過観察し得た悪性血管外皮細胞腫}

\section{菊池 章・喜連照夫（市立酒田）布施健生（山形大）原田次郎（山形県立中央）}

症例： 52 歳男性, 50 年 9 月右咽頭痛にて発症, 同月 当科初診, 上咽頭腫瑒摘出術施行. 52 年 5 月上咽頭腫 慯摘出術, 照射 $40 \mathrm{~Gy}$. 54 年 1 月照射 $40 \mathrm{~Gy}$, 凍結手術。 55 年 4 月上咽頭腫瑒摘出術, 照射 $50 \mathrm{~Gy} .56$ 年 1 月凍結 手術. 56年 7 月レーザー手術. 59年12月 ADR+DTIC 療法, 凍結手術。以後, 61年 4 月まで14回, 同様の治 療施行. 61 年 6 月咽頭腫瑒摘出術. 62 年 7 月咽頭腫瘍
摘出, 喉頭全摘, 下顎半切, 皮弁形成術, 以後 63 年 10 月まで12回, 腫瑒再発に対し，減量術施行するも，63 年10月16日死亡した。

手術時，大量出血をきたすので，クライオ，電気メ ス、レーザー、キューサー等を使用したが，いずれに ても出血の制御は困難であった。最終的には減量術施 行の際は, 用手的鈍的に腫崵摘出の後,アビテン，硝 